\title{
ARBORISTS IN LOUISIANA, U.S.: A BASELINE ASSESSMENT OF SAFETY AND PROFESSIONALISM
}

\section{By Hallie Dozier ${ }^{1}$ and Krisanna Machtmes ${ }^{2}$}

\begin{abstract}
In the mostly self-regulated arboricultural industry, Louisiana, U.S., is one of a few places where arborists must possess a license to operate. Since 1993, state-licensed arborists in Louisiana have been required to attend at least one continuing education workshop each year to maintain their licenses. In 2002, the State of Louisiana assumed responsibility for providing arborist continuing education, and program planners identified increasing safety and professionalism among licensed arborists as the two primary goals for the training program. The authors collected written questionnaires from 386 licensed arborists who provided baseline data on their levels of safety and professionalism and demographic information. Analysis suggested that safety and professionalism are not separate variables among respondents, but examination of categories of questions describing different aspects of safety and professionalism is revealing. Arborists self-reported good ethical practices in dealing with customers and a perception of being safe on the job, but they did not appear to be wholly familiar with current industry standards for safety and tree care. Respondents were less inclined to engage in recommended safety practices or to promote modern cultural practices to their clients. Unfamiliarity with current industry standards may be due to low participation in professional arboricultural societies among Louisiana licensed arborists and a tendency to attend the only the minimally required number of state-mandated educational events each year.

Key Words. Arboriculture; arborist; ISA; Louisiana; professional development; professional education; professional membership; professional training; program assessment; safety education; safety training; survey; TCIA.
\end{abstract}

Tree care, especially work involving pruning, climbing, and tree removal, has always been a dangerous occupation. Early arboriculture leaders focused more on perfecting pruning, pest management, and cavity work than safety, though interest in safety and safety training had grown by the 1930s (Blair 2001). Safe work practices and safety training have made steady gains since then, and in the early 1970s, U.S. national standards (American National Standard, Z133.1) were developed and approved (Blair 2001).

A search of the Internet revealed that most states in the United States have no minimum requirements for an arborist to practice, while others require only insurance to operate (Hawkins 2005), though there are some exceptions, including Louisiana, Maryland, and Virginia (Hull and Scott 2001; Murray 2002). Some European countries have extensive guidelines regulating various activities common to arboriculture, such as the United Kingdom's Approved Codes of Practice (McDermott 2005), and laws exists that address commercial use of chain saws, including work in and on trees (HSE 1999; EAC 2003a; Cottam 2005; Kolarík 2005). Other countries have few or no legal requirements (Kolarík 2005; O'Regan 2005). Despite widespread adoption of safety standards and advances in safety training since the early 1900s, current research confirms that tree care is a dangerous occupation and there continues to be a need for emphasis on safety training in this industry: almost 600 tree workers were killed on the job in the United States during the ten years from 1991 to 2000 (Ball and Vosberg 2003).

In addition to safety issues in this primarily selfregulated industry, arborists in the United States also suffer from a poor reputation among their clientele (Ball 1994). Arborists have not been the topic of much academic research, and there is little research-based information available about professionalism or ethical behavior among arborists. Nevertheless, industry leaders, including professional societies, heavily promote improving the professional image of arboriculture, advancing the profession, and raising the ethical bar among workers in tree care (Mills 2002; EAC 2003b; ISA 2004). Trade journals that target the tree care industry commonly urge arborists to improve themselves and the industry by making safety and professionalism top priorities on the job. The International Society of Arboriculture (ISA) certification program aims to promote and provide for more professional growth for arborists and to raise standards of the profession of arboriculture, and advertisements for the certification program refer to access to "research on new techniques" and "professional identity" as perks of membership (ISA 2004). Promotion of better arboriculture is also driven from outside the industry by groups such as Tree Amnesty, a grassroots citizen group in Seattle, Washington. Over the last several years, Tree Amnesty led a local campaign against topping that has succeeded in dramatically reducing the number of arborists who advertise topping as a service they provide (Turnbull 2004).

Arboriculture in Louisiana historically has not been strongly regulated (Roussel 2003), and unscrupulous practices remain common enough that there seems to be a general distrust of arborists by tree owners. Since the 1930s, Louisiana lawmakers have attempted to regulate the lawn care business, including care of trees and shrubs, and over 
the decades, statutes have become more and more specific to arboriculture. In 1979, it became mandatory for arborists to obtain a state license to practice, and the Louisiana Department of Agriculture and Forestry (LDAF) became the regulatory agency overseeing arborist licenses. In 1992, responding to the growing number of accidents involving arborists and their customers, Louisiana lawmakers dictated that, in addition to other licensing requirements, arborists must attend at least one continuing education training each year to maintain licensure (Roussel 2003).

From 1992 until 2002, a private professional society provided continuing education for licensed arborists. In 2002, the Louisiana State University Agricultural Center and Cooperative Extension Service (hereafter LSUAC) assumed this responsibility. Program organizers identified safety and professionalism as the two main training needs for enhancing the profession of arboriculture in Louisiana. This decision, to focus on safety and professionalism, grew out of advice from a steering committee composed of tree care and urban forestry professionals from across Louisiana and on common themes presented in trade and professional journals. The continuing education program includes formal assessment of the training's effectiveness. The objectives of this assessment are (1) to develop a baseline description of safety and professional practices of Louisiana arborists, and (2) to identify changes in safety and professional practices that result from the training. Here we present a baseline description of Louisiana arborists from the first year of data collection. Planned future work includes job-site observations and follow-up study to assess changes in arborist safety and professionalism 2 years after initiating the new program.

\section{METHODS}

We examined arborist safety and professionalism using a written questionnaire to collect information. We used Rasch analysis to evaluate the pilot questionnaire and, later, to test the modified questionnaire for its validity and reliability in measuring safety and professionalism and to create response variables for comparison of subgroups (e.g., male versus female).

\section{Statistical Analyses}

Rasch analysis, originally developed for use in psychological and educational testing, uses a logistic-odds ratio to (1) transform raw person scores (summed across questions) to a person score, and (2) transform raw question scores (summed across respondents) to a question score. Transformations are based on the probabilistic relationship between a question's difficulty and a respondent's ability to answer the question correctly. Question difficulty refers to the probability that a respondent will answer a question "correctly," that is, in a way that indicates safe or profes- sional behavior. Person ability refers to the proportion of questions a respondent is expected to answer correctly (e.g., the higher the person's ability, the more questions he or she will answer correctly). For this survey, a correct answer (yes) affirms safe or professional behavior and is coded as 1 (example: "I wear leg protection when on the job"). An "incorrect" answer (no) fails to affirm the behavior and receives the code 0 .

The Rasch model expresses the probability of responding to a question correctly as a function of the size of the difference between the person's ability and the question's difficulty (Bond and Fox 2001), and it provides a standardized, central, shared linear logistic scale that gives expected person ability and question difficulty values against which to compare individual questions and persons. Question score and person score estimates are expressed on a scale of logistics-odds ratios, or logits, with the average logit set to zero. Positive scores reflect higher than average probabilities, and negative scores reflect lower than average probabilities. A positive question score indicates that the question is more difficult than average for a respondent to answer "yes," (e.g., "I always keep both hands on the chain saw while making a cut"). A negative question score describes a question that is easier than average for the respondent to answer "yes" (e.g., "I recommend against topping"). Similarly, positive person score estimates identify respondents with higher than average levels of safety and professionalism. Negative estimates identify respondents whose responses indicate they are less professional and safe.

Another benefit of using Rasch analysis with a survey questionnaire is that it generates statistics useful in determining the quality of the questionnaire and the appropriateness of the survey respondents. These statistics are particularly useful during survey piloting and when determining sampling procedures, including identifying problematic questions (e.g., poorly worded or eliciting inappropriate information) and respondents (e.g., those who answer all questions the same way or who have large skip patterns in their responses). Verifying questionnaire quality and reliability and the appropriateness of the sampled population with Rasch-generated statistics allows broader interpretation of the results than would be possible with a traditional question-byquestion analysis. It also supports the survey as a good means for making interpretive statements regarding arborist safety and professionalism and for exploring questions about differences between subgroups.

\section{Questionnaire Development and Survey Procedures}

The pilot questionnaire contained 62 questions addressing the main constructs, or areas of interest, we wished to measure: professionalism and safety. Questions were based primarily on information provided in ISA's Arborists' 
Certification Study Guide (Lilly 2001), which serves as the guide for the Louisiana state arborist licensing exam (Roussel 2003). Each pilot question had five possible responses: 0 indicated a behavior that the respondent did not demonstrate ("never"), whereas a 1, 2, 3, or 4 indicated increasing frequency of a behavior the respondent demonstrated (e.g., "rarely" to "always").

Questions were written so that high scores indicated high levels of professionalism or safety and low scores indicated low levels. For example, following currently recommended safety practices (e.g., "I wear hearing protection when on the job" [Lilly 2001]) or being a member of a professional arborist society were considered traits of arborists demonstrating high levels of safety and professionalism, respectively. Structuring questions in this manner assumed that high levels would be more difficult for respondents to demonstrate because behaving more safely or professionally requires extra effort (e.g., to clean up a worksite, to do a job analysis) and/or expense (e.g., to purchase personal protective equipment). Questions were organized into seven domains, or categories, five related to professionalism and two related to safety (Table 1).

In May and June 2003, we collected pilot questionnaires from 112 workshop participants (response rate 96\%). Based on the analysis of the pilot survey, we eliminated four unsuitable questions and collapsed the 5-point categorical scale to a dichotomous scale $(0=$ no, $1=$ yes $)$. The revised questionnaire contained 58 questions relating to safety and professionalism in arboriculture. We administered revised questionnaires to 509 arborists who attended continuing education workshops from September 1, 2003, through April 2004. Of these 387, (78\%) were complete enough to use in the analysis. We analyzed questions measuring professionalism and safety with a dichotomous data model based on Rasch measurement theory (Bond and Fox 2001) using the WINSTEPS ${ }^{\odot}$ program (Linacre 2003).

Table 1. Categories of survey questions relating to safety and professionalism.

\begin{tabular}{lc}
\hline Question categories & $n$ \\
\hline Professionalism & \\
PET $=$ ethical business practices & 4 \\
PIC = interactions with customers & 8 \\
PSP = promotion of sound practices & 7 \\
PLE = follow local, state, and federal regulations & 4 \\
PTK = pursue technical training or & \\
membership in professional organization & 3 \\
Total & $\mathbf{2 6}$ \\
& \\
Safety & \\
SPC = perception of safety on the job & 4 \\
SBH = safety behavior & 28 \\
Total & $\mathbf{3 2}$ \\
\hline
\end{tabular}

\section{RESULTS}

Most respondents were white (84\%) men (92\%). Respondents tended to be young (Figure 1), and they were fairly well educated: $82 \%$ reported they had a high school degree or higher, and 16\% reported they had graduated from college. Most (72\%) lived in south Louisiana, where the greatest concentration of the state's population lives. A small number (2\%) of arborists who work in Louisiana live in neighboring states. Two-thirds (69\%) of the respondents owned their own business. Respondents had worked as arborists for an average of 12 years. Hispanic arborists had significantly higher person scores than white, black, or American Indian arborists (Table 2), but only three Hispanics responded to the survey, and they had worked in arboriculture only 4 years, on average. We did not detect any significant differences between any other subgroups (e.g., men versus women, business owners versus non-owners).

Table 2. Person measures for licensed arborists in Louisiana by ethnicity.

\begin{tabular}{lrl}
\hline Ethnicity & $n$ & Mean Rasch score \\
\hline American Indian & 20 & $2.9 \mathrm{~b}^{*}$ \\
Asian & 1 & 3.3 \\
Black & 20 & $2.7 \mathrm{~b}$ \\
Hispanic & 3 & $5.4 \mathrm{a}$ \\
White & 258 & $3.0 \mathrm{~b}$ \\
Other & 7 & 3.3 \\
\hline
\end{tabular}

"Means followed by a letter differ significantly $(P<0.05)$ based on Tukey's test.

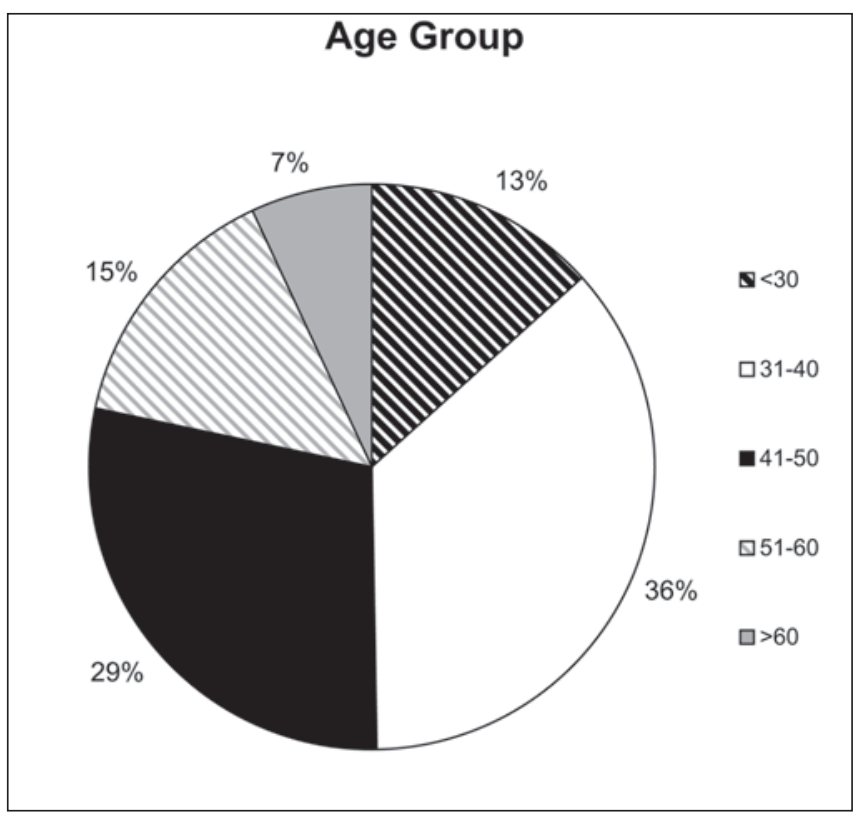

Figure 1. Age groups for licensed arborists in Louisiana. Half are 40 years old or younger. 
The analysis did not separate professionalism and safety as two distinct constructs. Rather, our questionnaire measured a single variable comprising seven domains, or question categories, among which there were discernible differences based on mean question difficulty (Figure 2). The easiest questions for respondents to answer correctly were those measuring ethical behavior (e.g., 98\% said they fulfilled all verbal and written contracts they made, and $99 \%$ indicated they maintained honesty in business practices). Similarly, questions about perception of safety on the job were easy for respondents (e.g., 98\% said they work under the safest possible conditions). This means that respondents scored high on the survey in terms of ethical behavior and how safe they feel on the job. They scored lower when it came to dealing with customers (e.g., 56\% reported they provide their customers with a written report). Measures were lowest for questions concerning adherence to state and federal laws (e.g., $73 \%$ said they display their license number on their work vehicles, a state regulation), hands-on safety behavior (e.g., $58 \%$ indicated they wore leg protection when on the job), making sound tree care recommendations, and pursuit of up-to-date technical information (e.g., 53\% said they attended more than one continuing education seminar each year, and $65 \%$ indicated they were members of a professional organization such as the International Society of Arboriculture).

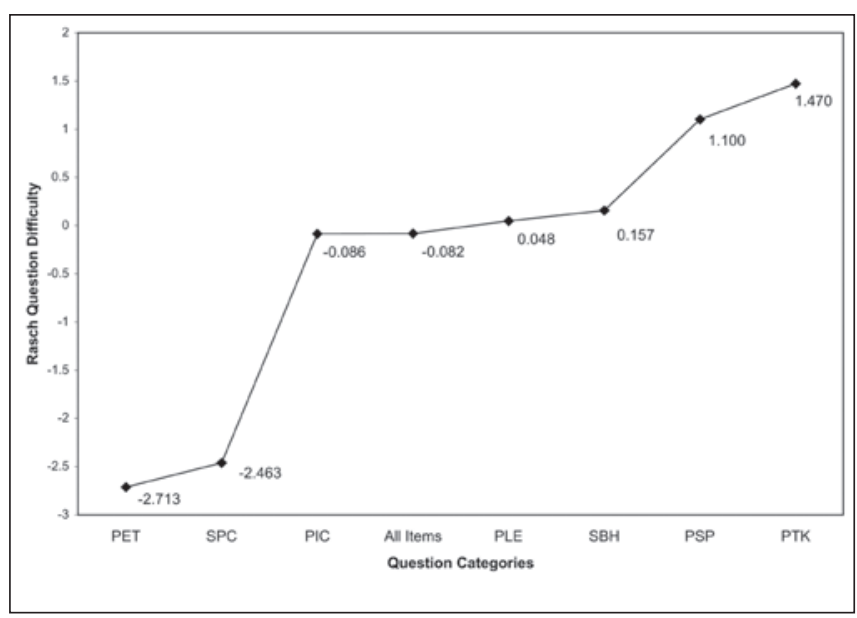

Figure 2. Mean survey question scores for seven question categories and mean question score for all questions. PET = ethical behavior in business practices; $\mathrm{PIC}=$ interactions with customers; $\mathbf{P S P}=$ promote sound arboricultural practices to customers; PTK = pursuit of technical training or membership in a professional organization; PLE $=$ ethics in following regulations; SPC = perception of safety on the job; and SBH = safety behaviors.

\section{DISCUSSION}

In this survey, respondents responded "yes" to most questions, effectively inflating their overall scores and exaggerating levels of professionalism and safety. Bias is not uncommon in self-reported surveys (Howard 1994; Schmitt 1994). Potential sources of bias-inflationary and deflationary-in self-reporting include social sensitivity of the subject of the survey (Fu et al. 1998), social desirability of the behaviors described by the questions (Arnold and Feldman 1981; Ashton 1998), pre-survey suggestion or "priming" (Ruble 1977; Moss and Lawrence 1997), and whether respondents are anonymous or identifiable (Malvin and Moskowitz 1983). To assess the extent of the bias in this survey, we will verify on-the-job professionalism and safety with direct observation during the second phase of the study.

Hispanic arborists scored higher than other arborists, but given their shorter careers in tree care (4 years for Hispanic arborists versus 12.4 for non-Hispanic) and the small number of Hispanic respondents in our sample (3), it is unlikely this difference is due to better knowledge or actual behavior. Rockwell and Kohn (1989) identified another potential source of inflationary bias in self-reported behavior on pre-tests or baseline surveys: initial unfamiliarity with content area. The difference this survey detected between Hispanic and non-Hispanic arborists may reflect the kind of inflationary bias that comes from unfamiliarity with content area for these reasons: (1) Hispanic arborists in Louisiana have worked fewer years in arboriculture than other ethnic groups, and (2) Hispanic workers may face substantial linguistic barriers when asked to complete a written questionnaire in English. Many newly immigrated Hispanic workers who enter agriculture-related or other green industry jobs are illiterate both in their own language and in English. For example, $85 \%$ of Mexican-born agricultural workers have less than a 12th grade education, and fewer than 5\% can read or speak English well (Mehta et al. 2000). The number of Hispanics working in tree care is growing across the country, and issues relating to their acquisition of knowledge and skills warrant further study and effort.

Our instrument failed to describe safety and professionalism as separate variables, suggesting they are closely related. Thus, the seven categories of questions we used (Table 1) are better independent indicators of sound arboricultural practice. Mean question scores ranged from easy for questions relating to ethical behavior in business practices $(-2.713)$ to difficult for questions relating to pursuit of technical training (1.470) (Figure 2). Questions indicating ethical behavior were the easiest for respondents to answer correctly, possibly because honesty and other ethical behaviors are such strongly desirable social behaviors that questions referring to honesty and ethics are easy to affirm regardless of actual practice. 
Questions regarding customer relations were more difficult for respondents to answer correctly. This finding may reflect customer relations and arborist reputation problems already noted by Ball (1994). This area deserves greater attention from researchers to identify the underlying causes of poor service provider/client relations.

Unlike broader areas of business ethics and customer relations, good arboricultural practices - especially technical skills, on-the-job behavior, and promotion of sound tree care practices-develop from specialized knowledge and experience. Respondents unfamiliar with industry standards and recommendations were less able to respond correctly to questions related to good arboricultural practices. Familiarity with (and adoption of) industry standards and recommendations depends largely on the individual's exposure to current, research-based information. This kind of information is most readily available through activities associated with membership in professional societies or frequent participation in educational activities such as continuing education workshops.

Almost all respondents (96\%) indicated they "seek out new information on tree care," but their responses to questions based on industry standards suggest that they do not employ currently recommended practices (e.g., advise against the use of amendments in the planting hole [Lilly 2001]). Moreover, the venues they use to gain specialized knowledge and become familiar with industry standards and recommendations were not clear from their responses. For example, with regard to participating in more than the minimum required number of continuing education workshops in order to gain new knowledge, over half of the respondents (52\%) said they attend two or more continuing education seminars each year. Registration records for the Louisiana program suggest that number is closer to $7 \%$, and fewer than 20 Louisianans attended ISA's annual conference in any of the past three years (Marx 2004).

Professional arboriculture societies serve as a primary source for trade and research-based information on arboriculture, and this information is readily available through memberships in these organizations. Respondents in this study seemed to over-report their membership activities. Two-thirds (238) indicated they were members of a professional society for arborists, but membership in the two largest professional arboricultural societies, ISA and the Tree Care Industry Association (TCIA), is very low among licensed arborists in Louisiana. There are 62 ISA members in Louisiana (Duchinksy 2005), but only 32 of them hold both a state license and ISA certification (6\%), a considerably smaller per capita number of working ISA members than in neighboring states of Texas or Arkansas, but a larger number than in other places (U.S. Census Bureau 2004; Duchinksy 2005; INSEE 2005; O'Regan 2005). Membership in TCIA is also quite low among Louisiana arborists. Only 12 individuals are members, and there are no TCIA accredited companies in the state (French 2004). Membership in the Louisiana Arborist Association is also low; 44 licensed arborists currently are listed on their member Web page (LAA 2005)

Low membership in professional arboriculture societies suggests limited access to current information about tree care, safety, and professionalism and may help explain why respondents in this study had low scores in terms of safety and technical knowledge. Members of ISA receive two educational publications (Journal of Arboriculture and Arborist News) that provide up-to-date information of topics related to tree care. Non-members may have access to these journals through colleagues, libraries, or on-line. ISA has 256 library memberships worldwide, 155 of which are in the United States (Butler 2005) and back issues (1999-2003) are available electronically online (TreeLink 2005). In Louisiana, three university libraries subscribe to Journal of Arboriculture.

TCIA publishes the trade journal, Tree Care Industry, for qualified tree company owners and others interested in arboriculture, 274 of whom have requested it in Louisiana (French 2004). Most Tree Care Industry recipients in Louisiana are business owners (licensed, certified or not). This survey indicates that $69 \%$ of state licensed arborists own their own businesses; thus, it is possible that a good number of licensed in Louisiana receive this journal.

Despite wide availability of these resources to arborists who do not participate in professional societies, this survey does not indicate that they take advantage of them.

In principle, the first step in becoming a licensed arborist in Louisiana is a basic familiarity with current industry standards both for tree care and safety; LDAF recommends that license applicants use the Arborists' Certification Study Guide to prepare for the state licensing exam, and the LSUAC training program offers an annual review course based on the Guide. Still, although examinees must be familiar with the Guide to receive a passing mark on the exam, survey respondents did not respond correctly to several questions taken directly from the Guide. Although they must know the material to succeed on the exam, they do not appear to retain much of the information they glean when they prepare to take the exam. This is not surprising, given they are required to attend only one educational seminar each year and they tend not to engage in activities that would expose them to new information (e.g., participation in professional societies). Their lack of familiarity with basic industry standards (e.g., using personal protective equipment) poses a considerable challenge for program directors who must deliver appropriate content to the audience members who need it most (e.g., those who currently do not use personal protective equipment) and also satisfy educational needs of those who have progressed beyond the basics and who are looking for more professional development. 
The desired outcomes for the LSUAC continuing education program are to improve safety and professionalism among licensed arborists. This study did not distinguish between safety and professionalism as separate behaviors; rather, it emphasizes that both types of behavior are fundamental components of good arboricultural practice. Louisiana arborists demonstrate some deficiencies in these areas, particularly in terms of on-the-job safety behaviors, promoting sound tree care practices to their customers, and pursuit of current technical information. These deficiencies lead us to conclude that promoting both professionalism and safety are appropriate training objectives for this program.

\section{LITERATURE CITED}

Arnold, H.J., and D.C. Feldman. 1981. Social desirability response bias in self-report choice situations. Acad. Manage. J. 24(2):377-385.

Ashton, M.C. 1998. Personality and job performance: The importance of narrow traits. J. Org. Behav. 19(3):289-303.

Ball, J. 1994. Plant health care and the public. J. Arboric. 20(1):33-37.

Ball, J., and S. Vosberg. 2003. How accidents happen and why: Arboriculture safety in the United States. Tree Care Industry 14(8):50-54.

Blair, D.F. 2001. The past, present and future of safety training for arborists. Tree Care Industry 12(10):8-12.

Bond, T.G., and C. M. Fox. 2001. Applying the Rasch Model: Fundamental Measurement in the Human Sciences. Lawrence Erlbaum Associates, Mahwah, NJ. 255 pp.

Butler, B. 2005. Personal communication. International Society of Arboriculture. January 18.

Cottam, M. 2005. Personal communication. Programme Leader for Arboriculture, Myerscough College, Bilsborrow, Preston, Lancashire, UK. February 4.

Duchinksy, E. 2005. Personal communication. International Society of Arboriculture, Champaign, IL. February 11.

European Arboricultural Council (EAC). 2003a. News from member countries. www.eac-arboriculture.com/ downloads/2/8/63/Newsletter12-03.pdf (accessed 7/25/05).

European Arboricultural Council (EAC). 2003b. News from the EAC. www.eac-arboriculture.com/downloads/2/8/ 63/Newsletter12-03.pdf (accessed 7/25/05).

French, B. 2004. Personal communication. Tree Care Industry Association, Manchester, NH. September 3.

Fu, H., J.E. Darroch, S.K. Henshaw, and E. Kolb. 1998. Measuring the extent of abortion underreporting in the 1995 National Survey of Family Growth. Fam. Plann. Perspect. 30(3):128-133, 138.

Hawkins, K. 2005. Personal communication. Louisiana State University School of Renewable Natural Resources, Baton Rouge, LA. January 12.
Health and Safety Executive (HSE). 1999. PUWER 98: How the regulations apply to agriculture and forestry. HSE Information Sheet. Agriculture Information Sheet No. 27. Sudbury, Suffolk, UK. 4 pp.

Howard, G.S. 1994. Why do people say nasty things about self-reports? J. Org. Behav. 15:399-404.

Hull, R.D., and J.M. Scott. 2001. House Bill No. 2100. Virginia House of Delegates, Richmond, VA.

Institut National de la Statistique et des Etudes (INSEE). 2005. The French population in 2003. www.insee.fr/en/ ffc/pop_age3.htm (accessed 7/25/06).

International Society of Arboriculture (ISA). 2004. ISA Strategic Plan 2001-2005. www.isa-arbor.org/about/ strategic.aspx (accessed 7/25/05).

Kolarík, J. 2005. Personal communication. Safe Trees, s.r.o., Na Stepnici, Czech Republic. January 29.

Lilly, S.J. 2001. Arborists' Certification Study Guide. International Society of Arboriculture, Champaign, IL. 222 pp.

Linacre, J.M. 2003. Optimizing rating scale category effectiveness. J. Appl. Measure. 3(1):85-106.

Louisiana Arborist Association (LAA). 2005. Complete membership of Louisiana Arborist Association. www.louisianaarborist.com/members/index.html (accessed 7/25/05).

Malvin, J.H., and J.M. Moskowitz. 1983. Anonymous versus identifiable self-reports of adolescent drug attitudes, intentions, and use. Pub. Opin. Q. 47(4):557-566.

Marx, J. 2004. Personal communication. International Society of Arboriculture, Champaign, IL. September 3.

McDermott, I. 2005. Personal communication. International Society of Arboriculture UK\&I Chapter, Wednesbury, West Midlands, UK. February 5.

Mehta, K., S. Gabbard, V. Barrat, M. Lewis, D. Carroll, and R. Mines. 2000. Findings from the National Agricultural Workers Survey (NAWS) 1997-1998: A Demographic and Employment Profile of United States Farmworkers. www.doleta.gov/agworker/report_8.pdf (accessed 7/25/05).

Mills, C. 2002. How are we to define ourselves? Tree Care Industry 13(8):2.

Moss, S.E., and K.G. Lawrence. 1997. The effects of priming on the self-reporting of perceived stressors and strains. J. Org. Behav. 18(4):393-403.

Murray, J. 2002. The role of community colleges in training arborists to care for Virginia's urban forests. Inquiry 7(1):55-63.

O’Regan, P. 2005. Personal communication. Société française d'arboriculture, Nérac, France. February 8.

Rockwell, S.K., and H. Kohn. 1989. Post-Then-Pre Evaluation. J. Extension. 27(2). www.joe.org/joe/ 1989summer/a5.html (accessed 7/25/05).

Roussel, C. 2003. Personal communication. Louisiana Department of Agriculture and Forestry, Baton Rouge, LA. February 4. 
Ruble, D.N. 1977. Premenstrual symptoms: A reinterpretation. Science 197(4300):291-292.

Schmitt, N. 1994. Methods bias: The importance of theory and measurement. J. Org. Behav. 15:393-398.

TreeLink. 2005. Journal of Arboriculture Archive. www.treelink.org/joa/ (accessed 7/25/05).

Turnbull, C. 2004. From the garden of Cass Turnbull. Arborist News 13(3):69-71.

U.S. Census Bureau. 2004. Annual Estimates of the Population for the United States and States, and for Puerto Rico: April 1, 2000 to July 1, 2004. www.census.gov/popest/states/tables/NST-EST200401.xls (accessed 7/25/05).

I*Assistant Professor
School of Renewable Natural Resources
Louisiana State University Agricultural Center
Baton Rouge, LA, 70803, U.S.
hdozier@lsu.edu

${ }^{2}$ Assistant Professor

School of Human Resources Education and Workforce Development

Louisiana State University

Baton Rouge, LA, 70803, U.S.

machtme@lsu.edu

*Corresponding author.

Résumé. Au sein de l'industrie arboricole autorégulée, la Louisiane est l'un des seuls endroits où les arboriculteurs doivent posséder un permis pour opérer. Depuis 1993, les arboriculteurs licenciés de Louisiane sont requis d'assister à au moins un atelier d'éducation continue par année pour maintenir leur permis. En 2002, l'état de Louisiane a pris la responsabilité de fournir aux arboriculteurs une éducation continue et les planificateurs du programme ont alors identifié l'accroissement de la sécurité et du professionnalisme comme les deux objectifs clés du programme de formation. Les auteurs ont colligé les informations de questionnaires auprès de 386 arboriculteurs licenciés qui ont fourni des informations de base sur leurs niveaux de sécurité et de professionnalisme ainsi que des informations de nature démographique. Lanalyse faite suggère que la sécurité et le professionnalisme ne sont pas des variables distinctes parmi les répondants, mais l'examen des catégories de questions décrivant les différents aspects de la sécurité et du professionnalisme sont révélatrices. Les arboriculteurs ont rapporté d'eux-mêmes de bonnes pratiques éthiques lorsqu'ils transigent avec les consommateurs ainsi que l'impression de travailler de manière sécuritaire, mais ils n'apparaissent pas pour autant être entièrement familiers avec les normes courantes de sécurité et de travail de l'industrie. Les répondants étaient moins enclins à s'engager envers des pratiques sécuritaires recommandées ou encore de promouvoir des pratiques culturales modernes auprès de leurs clients. La manque de familiarité avec les normes courantes de l'industrie pourrait être dû à un faible taux de participation au sein des sociétés professionnelles d'arboriculture parmi les arboriculteurs licenciés de Louisiane, ainsi qu'une tendance à n'assister qu'au minimum d'événements éducationnels requis par l'état annuellement.

Zusammenfassung. In der sich überwiegend selbst regulierenden Baumpflegeindustrie ist Louisiana, USA, einer der wenigen Bundesstaaten, wo Arboristen eine Lizenz zum Arbeiten erwerben müssen. Seit 1993 wird von staatlich lizenzierten Arboristen erwartet, dass sie mindestens einen fortlaufenden Ausbildungs-Workshop pro Jahr besuchen, um ihre Lizenz zu erhalten. 2002 übernahm der Bundesstaat Louisiana Verantwortung für das Angebot fortlaufender Ausbildung für Baumpfleger und die Programmplaner identifizierten wachsende Sicherheit und Professionalität als die zwei Trainingsschwerpunkte bei den lizenzierten Arboristen. Die Autoren sammelten schriftliche Fragebögen von 386 lizenzierten Arboristen, die grundsätzliche Daten über ihren Grad an Sicherheit, Berufserfahrung und demografische Informationen lieferten. Die Analysen ergaben, dass Sicherheit und Professionalität keine separaten Faktoren bei den Befragten waren, aber eine Untersuchung der Fragekategorien bezüglich der unterschiedlichen Aspekte von Sicherheit und Professionalität steht noch aus. Die Arboristen berichteten über gute Berufsethik im Umgang mit Kunden und ein Bewusstsein für Arbeitssicherheit vor Ort, aber sie schienen nicht ausreichend vertraut zu sein mit den gegenwärtigen industriellen Standards für Sicherheit und Baumpflege. Die Teilnehmer der Umfrage waren weniger bereit, empfohlene Sicherheitsbestimmungen anzuwenden oder moderne Arbeitsweisen ihren Kunden zu verdeutlichen. Unsicherheit mit gegenwärtigen industriellen Standards könnte an der geringen Beteiligung an professionellen Baumpflegegesellschaften unter den lizenzierten Arboristen in Louisiana liegen und an der Tendenz, nur die notwendigsten staatlich verordneten Kurse zu besuchen.

Resumen. Louisiana, USA es uno de los pocos lugares en donde los arboristas deben poseer una licencia para operar. Desde 1993, los arboristas han requerido asistir al menos a un taller de educación cada año para mantener la licencia. En el 2002, el Estado de Louisiana asumió la responsabilidad de proporcionar educación continua, y los planeadores identificaron incremento en seguridad y profesionalismo entre los arboristas licenciados, como los dos primeros objetivos para el programa de entrenamiento. Los autores colectaron cuestionarios escritos de 386 arboristas licenciados quienes proporcionaron los datos base en sus niveles de seguridad y profesionalismo e información demográfica. El análisis sugiere que la seguridad y el profesionalismo no son variables separadas entre los que respondieron, pero el examen de categorías de preguntas que describen diferentes aspectos de seguridad y profesionalismo es revelador. Los arboristas reportaron buenas prácticas éticas en relación con los consumidores y una percepción de bienestar en el trabajo, pero no parecen del todo familiarizados con los estándares actuales de la industria para seguridad en el trabajo con los árboles. Los respondientes estuvieron menos inclinados a comprometerse en prácticas de seguridad o promover prácticas culturales modernas a sus clientes. Esta situación con los estándares actuales de la industria puede ser debida a la baja participación en sociedades profesionales de arboricultura entre los arboristas licenciados de Louisiana y una tendencia a atender una mínima parte de los eventos de educación requeridos cada año. 